\title{
Adaptation of Situ Bagendit, Rindang 1 and Rindang 2 Varieties in Shallow Swamp Ogan Komering Ilir District South Sumatera
}

\author{
Joni Karman $^{1, *}$, Suparwoto ${ }^{1}$, and Waluyo ${ }^{1}$ \\ ${ }^{1}$ South Sumatera Assessment Institute for Agricultural Technology, Indonesia
}

\begin{abstract}
Shallow swamps can be used for rice production during the dry season. The problem that occurs is lack of water. The technology needed to overcome these problems is drought tolerant superior varieties. The purpose of this study is to obtain superior varieties tolerant to drought on shallow lebak swampy. The study was conducted from April 2019 to August 2019. The varieties used were Situ bagendit, Rindang 1, Rindang 2, and the Siam (local) as comparison. Data collected included: plant height, number of productive tillers, number of grains per panicle, number of filled grains per panicle, number of empty grains per panicle and production. The method used is direct observation in the field. The data obtained were compiled by tabulation and analyzed by statistical tests namely the similarity test of the middle value (t-test). The results showed that the varieties Situ Bagendit, Rindang 1, and Rindang 2 had better numbers of productive tillers, number of grains per panicle, and number of filled grains per panicle than Siam varieties. The highest production was achieved by the Situ Bagendit variety, namely 4.6 tonnes/ha. Meanwhile, the production of Rindang 2, Rindang 1, and Siam varieties were 4.4; 4.0; and 2.0 tonnes/ha.
\end{abstract}

\section{Introduction}

The provision of food, especially rice, is a major concern of the government. As a result of land conversion on the fertile lands as on the island of Java, the development of the rice crop is diverted outside of Java such as the island of Sumatra. The largest land area on the island of Sumatra is swamp land in the province of South Sumatra. Based on the agroecosystem, swamps are divided into tidal swamps and lebak swamps. Regional Development rice agro-ecosystem directed to lowland swamp that still require attention, especially in Ogan Ilir that has the widest swampy marsh. Constraints that exist are high inundation and duration of inundation, so there are three categories of lebak namely shallow, mid-level and deep shallow. During the dry season there is drought and the rainy season floods. Generally, rice is planted in the dry season. Rice planting depends on water conditions. The planting start from shallow swamp, next to the middle swamp, and finally to the deep swamp. So rice production from the three typologies varies. Drought first

\footnotetext{
*Corresponding author: jkarman3@gmail.com
} 
occurs in the shallow swamp then followed by the middle swamp and deep swamp. Then planting first performed on the swampy shallows by the low tide. Shallow swamp land are encouraged to increase the production of rice $[4,20]$. The increase in production was mainly contributed by the use of improved varieties. Superior varieties are technologies that are easy to apply, environmentally friendly, inexpensive, affordable for farmers $[1,18]$. The use of high-yielding varieties over a long period of time will result in decreased resistance of varieties due to the emergence of new pest biotypes and disease strains that have an impact on reducing rice productivity [12].

Arinta and Iskandar said that the increase in rice productivity could be achieve by using superior varieties that have high yields, early maturity, resistance to pests and diseases. The superior varieties commonly used by farmers are Ciherang, IR 42, Sentani, Ciliwung and local varieties namely Siam, Siputih and Pegagan which can produce productivity of 2.03.0 tons/ha [2]. In the shallow swamp land there is often a lack of water. Lack of water occurs because the availability of water cannot meet the needs of plants and excessive evapotranspiration [21]. Drought tolerant rice varieties are needed to anticipate drought during plant growth. Drought tolerant rice plants are rice plants that are able to adapt to water shortage conditions and grain yields do not decrease significantly. Decrease in grain yield is determined by the level of drought, the period of water shortage and the phase of plant growth [14]. Drought occurs because rainfall is less than evapotranspiration and water uptake by roots cannot compensate for the amount of evapotranspiration so that there is a decrease in evapotranspiration which affects the decrease in crop production [8]. The growth phases of rice plants that are vulnerable to water deficiency are the initial phases of vegetative growth, flowering and grain filling [7]. One of the criteria for rice plants can grow in limited rainfall and is an ideal plant are 1) Plant growth in accordance with water availability, 2) High yield potential and 3) Able to maintain plant greenness during drought and drought tolerant [5]. So to anticipate during the growth of rice plants against drought, drought tolerant rice varieties are used. Characteristics of drought tolerant rice varieties include stems somewhat erect, resistant to blast disease, tolerant of Al. These varieties include Situ Bagendit, Rindang 1 and Rindang 2 with an average yield of 4.0-4.6 tons/ha. Kalimutu, Cisokan, Situ Patenggang, and Gilirang varieties have a high level of tolerance to drought. Based on these conditions, the aim of this study was to obtain superior varieties that have drought tolerant in shallow lowland swamps [21].

\section{Research Methods}

The research location was in Sugiwaras Village, Ogan Komering Ilir District, South Sumatra, on farmer's land with shallow lowland swamp agroecosystems, starting April 2019 to August 2019 in the 2019 dry season. The varieties used were Situ Bagendit, Rindang 1, Rindang 2, and Siam (local) as comparator. Variety descriptions can be seen in table 1 . The seeds are sown on processed beds after 3 weeks of age after sowing are transferred to the second bed because the land is still dry. When it rains, the seeds are planted so that they are 35 days old after sowing. The spacing of the tile system is $25 \times 25$ $\mathrm{cm}$ and the number of seeds is 2-3 seeds / hole. The application of urea fertilizer at a dose of 150 per hectare was given twice, when the plants were one week after planting and four week after planting, half dose for each application. While SP-36 fertilizer at a dose of 100 $\mathrm{kg}$ per ha and KCL fertilizer at a dose of $100 \mathrm{~kg}$ per ha are given when the plants at one week after planting. The data collected included: plant height, number of productive tillers, number of grains per panicle, number of filled grains per panicle, number of empty grain per panicle and production. Data obtained tabulation compiled and analyzed with statistical test (t-test). Data analysis using the SPSS 11 application. 
Table 1. Description of Situ Bagendit, Ridang 1 and Ridang 2 varieties [3]

\begin{tabular}{|c|c|c|c|c|}
\hline No & Description & Situ Bagendit & Rindang 1 & Rindang 2 \\
\hline 1 & Plant height $(\mathrm{cm})$ & $99-105$ & 130 & 138 \\
\hline 2 & Plant age (hari) & $110-120$ & 113 & 113 \\
\hline 3 & Flag leaf & Upright & slightly tilted & slightly tilted \\
\hline 4 & Loss & Moderate & Moderate & Moderate \\
\hline 6 & Rice texture & Pulen & Pera & Pulen \\
\hline 7 & 1000 grain weight & $27-28$ & $27.6 \mathrm{gr}$ & 13.3 \\
\hline 8 & Average of yield & $\begin{array}{l}4.0 \text { ton/ha in dry land } \\
5.5 \text { ton/ha in the } \\
\text { paddy field }\end{array}$ & 4.6 ton/ha & 4.2 \\
\hline 9 & $\begin{array}{l}\text { Potential of } \\
\text { production }\end{array}$ & 6.0 ton/ha & 6.9 ton/ha & 7.39 ton/ha \\
\hline 10 & Pest & Susceptible to WBC & $\begin{array}{l}\text { Slightly sensitive to } \\
\text { WBC biotypes } 1,2 \text {, and } \\
3\end{array}$ & $\begin{array}{l}\text { Slightly } \\
\text { sensitive to } \\
\text { WBC biotypes } \\
1,2 \text {, and } 3\end{array}$ \\
\hline 11 & Disease & $\begin{array}{l}\text { Slightly resistant to } \\
\text { blast } \\
\text { Slightly resistant to } \\
\text { bacterial leaf blight } \\
\text { strains III and IV }\end{array}$ & $\begin{array}{l}\text { Resistant to blast ras } \\
001,041,033 \\
\text { Slightly resistant to } \\
\text { blast ras } 173\end{array}$ & $\begin{array}{l}\text { Resistant to blast } \\
\text { ras } 001,041, \\
033, \\
\text { Slightly resistant } \\
\text { to blast } 073,051 \\
\end{array}$ \\
\hline 12 & Abiotic stress & $\begin{array}{l}\text { Slightly tolerant to } \\
\text { drought }\end{array}$ & $\begin{array}{l}\text { Shade tolerant } \\
\text { Slightly tolerant to } \\
\text { drought } \\
\text { Tolerant to Al toxicity } \\
40 \mathrm{ppm}\end{array}$ & $\begin{array}{l}\text { Slightly tolerant } \\
\text { to shade and } \\
\text { drought } \\
\text { Highly tolerant } \\
\text { to Al toxicity } 40 \\
\text { ppm }\end{array}$ \\
\hline 13 & $\begin{array}{l}\text { planting } \\
\text { recommendations }\end{array}$ & $\begin{array}{l}\text { Suitable for planting } \\
\text { on dry land or planted } \\
\text { in paddy fields }\end{array}$ & $\begin{array}{l}\text { Well planted on dry } \\
\text { land lowland }\end{array}$ & $\begin{array}{l}\text { Well planted on } \\
\text { dry land lowland }\end{array}$ \\
\hline
\end{tabular}

\section{Result and Discussion}

The results of statistical analysis showed that Situ Bagendit plant height was significantly different from Rindang 1, Rindang 2 and local Siam varieties, but Rindang 1 was not significantly different from Rindang 2 . The height of Rindang 2 and Rindang 1 plants was significantly different from Siam (local) (Table 2).

It can be seen from Tabel 2 that the height of the Situ Bagendit, Rindang 1 and Rindang 2 plants is shorter than that of local Siam. Situ Bagendit is a plant that has a short stature of $101.4 \mathrm{~cm}$, while local vaeriety (Siam) has a height growth posture of $123.8 \mathrm{~cm}$. Based on the understanding from farmers that the varieties Rindang 1, Rindang 2 and local Siam tend to collapse due to wind gusts. It seen from the description of each variety that these varieties decreased due to plant height than the drought. The local varieties of Siam experience fall down of about $25 \%$ because they have a high growth posture compared to other varieties that have resistance to fall down. Drought in the shallow swamp will affect the plant's morphological and physiological activities, thereby inhibiting growth and even crop failure. Photosynthesis is a vital process for growth and development of crop, which is most sensitive to water stress basically in higher plants [16]. Mild water deficiency results in slow shoot growth, reduced stem lengthening and leaf enlargement. 
Table 2. The average height of superior rice varieties in Sugiwaras Village, Ogan Komering Ilir District

\begin{tabular}{|l|l|l|l|l|}
\hline Varieties & Rata-rata & Situ Bagendit & Rindang 2 & Rindang 1 \\
\hline Situ Bagendit & 101.4 & - & & \\
\hline Rindang 2 & 115.2 & $* *$ & - & \\
\hline Rindang 1 & 115.4 & $* *$ & ns & - \\
\hline Siam (lokal) & 123.8 & $* *$ & $*$ & $*$ \\
\hline Average & 113,9 & & & \\
Information : $* *$ & $=$ highly significant (Probability $<0.01)$ \\
& $*=$ significant (Probability $<0.05)$ \\
ns & $=$ not significant (Probability $>0.05)$
\end{tabular}

\subsection{Number of productive tillers}

Results of statistical analysis show the number of productive tillers Situ Bagendit varieties, Rindang 1, Rindang 2 were not significantly but highly significant to the local Siam. The number of productive tillers from local Siam was 10.2 stems on average, while drought tolerant varieties were 17.0 stems on average (Table 3 ).

Table 3. The average number of productive tillers of superior varieties in Sugiwaras Village, Ogan Komering Ilir District

\begin{tabular}{|c|c|c|c|c|}
\hline Varieties & Average & Situ Bagendit & Rindang 2 & Rindang 1 \\
\hline Situ Bagendit & 17.4 & - & & \\
\hline Rindang 2 & 17.4 & $\mathrm{~ns}$ & - & \\
\hline Rindang 1 & 16.4 & ns & ns & - \\
\hline Siam (lokal) & 10.2 & ** & ** & ** \\
\hline Rata-rata & 15.4 & & & \\
\hline
\end{tabular}

Table 3 shows that the number of productive tillers of varieties Situ Bagendit, Rindang 1 and Rindang 2 more than local variety because Siam variety is not resistant to lack of water and the seeds used to multiply the results themselves and planted each season. Meanwhile, the three varieties were resistant to water deficiency conditions so that they were able to form more tillers than the Siam counterpart. Said by Ichsan et al. (2015) that each variety has different adaptability to drought. The number of productive tillers of the four varieties are vary, due to genetic factors and environmental factors where these varieties are planted [22]. Different varieties will show a growth response and yield will be different even if planted in the same environment. The drought that occurs during the maximum tiller formation phase and the flowering phase will significantly reduce rice yields [15]. Drought represents the most important and frequent limiting factor for crop establishment [14]. Sugeng (2001) stated that the factors influence the formation of tillers are spacing, fertilizers, varieties and planting season. In addition, marginal environment, such as lack of water, less fertile land, old seedlings can also affect the number of tillers of rice plants [17].

\subsection{Number of grain per panicles}

Statistical analysis showed that the number of grain/panicle varieties Situ Bagendit, Rindang 1, 2 Rindang highly significant to the local Siam but high-yielding varieties were not significantly different (Table 4). 
Table 4. The average number of superior varieties of grain/panicle in Sugiwaras Village, Ogan Komering Ilir District

\begin{tabular}{|c|c|c|c|c|}
\hline Varieties & Average & Situ Bagendit & Rindang 2 & Rindang 1 \\
\hline Situ Bagendit & 162.4 & - & & \\
\hline Rindang 2 & 156.2 & ns & - & \\
\hline Rindang 1 & 159.8 & $\mathrm{~ns}$ & ns & - \\
\hline Siam (lokal) & 113.4 & $* *$ & ** & $* *$ \\
\hline Average & 147.95 & & & \\
\hline
\end{tabular}

Table 4, shows that the number of grains per panicle of each variety varies from 113.1162.4 grains where the highest number of grains is 162.4 , which is achieved by Situ Bagendit and Siam varieties has only 113.4 grains. So that the Situ Bagendit, Rindang 1 and Rindang 2 varieties can still show the highest number of grain per panicle in water shortage conditions. When water is not sufficient then the grain formation process is not perfect, so the effect on the percentage of empty grain increased [8].

\subsection{Number of filled grain per panicle}

Situ bagendit varietiy have filled grain/panicle most compared to other varieties, namely 136.8 grains, but the high-yielding varieties have filled grain/panicle best despite the lack of water so that the land can be said to three of these varieties are adapted to shallow swampy wetlands. Apart from environmental factors, the number of grains per panicle of a variety is also influenced by genitives factors where the variety has different filled grain per panicle. Drought and flood affect the percentage of filled grain in rice, depended on the degrees of drought and flooding [10].

Table 5. Average number of filled grain/panicles of superior varieties in Sugiwaras Village, Ogan Komering Ilir District

\begin{tabular}{|l|l|l|l|l|}
\hline Varieties & Average & Situ Bagendit & Rindang 2 & Rindang 1 \\
\hline Situ Bagendit & 136.8 & - & & \\
\hline Rindang 2 & 125.8 & ns & - & \\
\hline Rindang 1 & 129.4 & ns & ns & - \\
\hline Siam (lokal) & 95.0 & $* *$ & $* *$ & $* *$ \\
\hline Average & 121.75 & & & \\
\hline Information : $* *$ & $=$ highly significant (Probability $<0.01)$ \\
& $*=$ \\
ns & $=$ not significant (Probability $<0.05)$ \\
\end{tabular}

\subsection{Number of empty grain per panicle}

The results of the statistical analysis showed that the number of empty grains / panicles of Situ Bagendit, Rindang 1 and Rindang 2 varieties were not significantly different from local Siam. Meanwhile, Situ Bagendit was significantly different from Rindang 1 and Rindang 2 (Table 6).

The data listed in Table 5 shows that all the varieties studied had varied empty grain per panicle due to the influence of external factors, namely lack of water. The highest number of empty grain was owned by the Siam variety, namely $22.6 \%$, while the superior varieties were drought tolerant in the range of $11.3-19.5 \%$. The small number of empty grain per panicle, namely Situ Bagendit (11.3\%). These parameters can describe the yield of grain obtained, where the percentage of empty grain is a little predictable high grain yield. If 
there is a lack of water at the flower formation stage, there will be a decrease in the number of grains per panicle, and if it occurs at the pollination / fertilization stage, there will be an increase in the number of empty grain per panicle [21].

Table 6. Average number of empty grain/panicles superior varieties in Sugiwaras Village, Ogan Komering Ilir District

\begin{tabular}{|c|c|c|c|c|}
\hline Varietas & Rata-rata & Situ Bagendit & Rindang 2 & Rindang 1 \\
\hline Situ Bagendit & $18.4(11.3 \%)$ & - & & \\
\hline Rindang 2 & $30.4(19.5 \%)$ & $*$ & - & \\
\hline Rindang 1 & $30.4(19.0 \%)$ & $*$ & tn & - \\
\hline Siam (lokal) & $25.6(22.6 \%)$ & tn & tn & tn \\
\hline Rata-rata & 26.2 & & & \\
\hline
\end{tabular}

\subsection{Grain production}

The results of statistical analysis on grain production of Situ Bagendit, Rindang 1, and Rindang 2 varieties were very significantly different from Siam variety, but Situ Bagendit was not significantly different from Rindang 2 (Table 7).

Table 7. Average grain production (tonnes of GKP / ha) superior varieties in Sugiwaras Village, Ogan Komering Ilir District

\begin{tabular}{|l|l|l|l|l|}
\hline Varietas & Average & Situ Bagendit & Rindang 2 & Rindang 1 \\
\hline Situ Bagendit & 4.6 & - & & \\
\hline Rindang 2 & 4.4 & ns & - & \\
\hline Rindang 1 & 4.0 & $* *$ & $*$ & - \\
\hline Siam (lokal) & 2.0 & $* *$ & $* *$ & $* *$ \\
\hline Average & \multicolumn{3}{|l|}{} \\
Information : ** & $=$ highly significant (Probability $<0.01)$ \\
& $*$ \\
& $=$ significant (Probability $<0.05)$ \\
ns & $=$ not significant (Probability $>0.05)$
\end{tabular}

Table 7 shows that the productivity of Situ Bagendit, Rindang 2, and Rindang 1 grains are higher than Siam, ranging from 4.0-4.6 tons/ha with a successive difference of 2.6; 2,4; 2.0 ton/ha. This is due to the Situ Bagendit, Rindang 2, and Rindang 1 varieties have the higher number of productive tillers, grain/panicle, filled grain/panicle, meanwhile the number of empty grain/panicle is lower. The highest grain productivity was achieved by Situ Bagendit, namely 4.6 tonnes /ha, higher than the average yield of its description, namely 4.0 tonnes/ha, while Rindang 2 was also higher than the description, namely 4.4 tonnes/ha and Rindang 1, namely 4.0 ton/ha. Lack of water in the generative phase has an effect on decreasing flowering, the number of grains, the weight of 1000 grains of grain and the large number of empty grains [6]. Drought during vegetative growth, well before the onset offlowering, canreduce yield by reducing the growth of photosynthetic and storage organs [13]. As drought stress proceeds, stomatal closure induces the limitation of photosynthesis by carbon, and the use of energy for photosynthesis then becomes lower than the absorbed light energy [11]. Suparwoto reports that if lack of water occurs when the plant is in the flowering phase, it will affect the decrease in the number of grain grains [18]. Furthermore, Jonharnas et al., stated that the number of filled grains / panicles and the large number of productive tillers will give higher yields [11]. 


\section{Conclusion}

The results showed that the varieties Situ Bagendit, Rindang 1, and Rindang 2 had better numbers of productive tillers, number of grains per panicle, and number of filled grains per panicle than Siam varieties. The highest production was achieved by the Situ Bagendit variety, namely 4.6 tonnes/ha. Meanwhile, the production of Rindang 2, Rindang 1, and Siam varieties were $4.4 ; 4.0$; and 2.0 tonnes/ha.

\section{References}

1. Arora, A., S. Bansal, P.S. Ward. Water Resources and Economics, 25, 27-41, (2019)

2. Arinta, K dan Iskandar Lubis. Buletin Agrohorti, 6 (2) : 270-280, (2018)

3. Badan Litbang Pertanian. Deskripsi varietas unggul baru padi. (Badan Penelitian dan Pengembangan Pertanian, Kementerian Pertanian, 2019)

4. Bappenas. Proyeksi penduduk Indonesia. (Badan Perencanaan Pembungan Nasional, 2013)

5. Budiasih. Ganec Swara Edisi Khusus 3 (3):22-27, (2009)

6. Effendi, Y. Kajian risestensi beberapa varietas padi gogo terhadap cekaman kekeringan. (Universitas Sebelas Maret Surakarta, 2008)

7. Estiningtyas, W dan Syakir, M. Jurnal Meteorologi dan Geofisika 18 (2):83-93, (2017)

8. Fauza, Y. Pengaruh cekaman kekeringan terhadap pertumbuhan dan produksi galurgalur padi sawah. (Institut Pertanian Bogor, 2013)

9. Girsang, S.S., dan D. Parhusip. Prosiding Seminar Nasional Inovasi Pertanian Spesifik Lokasi. Buku 1328 - 333, (2013)

10. Huang, J., Hu, T., Yasir, M. Gao, Y., Chen, C., Zhu, R., Wang, X., Yuan, H., and Yang, J. Environmental and Experimental Botany, 157, 11-25, (2019)

11. Iseki, K., K. Homma, T. Shiraiwa, B. Jongdee, P. Mekwatanakarn. 2014. Field Crops Research 163, 18 - 23, (2014)

12. Jonharnas, N. Chairuman dan Syahrul Zen. Prosiding Seminar Nasional Hasil Penelitian Padi 2009, Buku I. Balai Besar Penelitian Tanaman Padi Sukamandi. (2010)

13. Korres, N.E., J.K. Norsworthy, N.R. Burgos, and D.M. Oosterhuis. Water resources and rural development 9, $12-17,(2017)$

14. Lamichhane J.R., and E. Soltani. Journal of Agriculture and Food Research, 2, 100089, (2020)

15. Mulyaningsih, S.E, H.Aswidinnoor, D.Sopandie, P.B.F.Ouwerkerk, I.H.S. Loedin. 2010. Jurnal Pertanian Tanaman Pangan 29, (2):72-81, (2010)

16. Nahara, S., L. Sahoob, B. Tantia. Biocatalysis and Agricultural Biotechnology, 15, 150$159,(2018)$

17. Rois, A.Syukur, Z.Basri. Jurnal Agroland ,24 (3):237-241, (2017)

18. Suhendrata, T. Jurnal SEPA, 13, (2):188-194, (2017)

19. Suparwoto. Dalam: Maesti, M, Siti, S.T, Yovita, A.D, Vyta, W.H, Nafiah, A (Ed). Inovasi Teknologi Pertanian dalam Pendampingan Berbasis Kawasan Penerbit: IAARD PRESS Badan Penelitian dan Pengembangan Pertanian. Jakarta. Hal.77-88, (2019)

20. Suryana. Jurnal Penelitian dan Pengembangan Pertanian, 35 (2): 57-68, (2016)

21. Sujinah, dan A. Jamil. Iptek Tanaman Pangan 11 (1):1-7, (2016) 
22. Syaputra, A, Nurhayati, dan C.N. Ichsan. Jurnal Ilmiah Mahasiswa Pertanian 3 (2):128$135,(2018)$ 